\title{
SILICON HALIDE-ALKALI METAL FLAMES AS A SOURCE OF SOLAR
} GRADE SILICON

Seventh Quarterly Report

By

D. B. Olson

R. K. Gould

April 1979

Work Performed Under Contract No. NAS-7-100-954777

AeroChem Research Laboratories, Inc.

Princeton, New Jersey

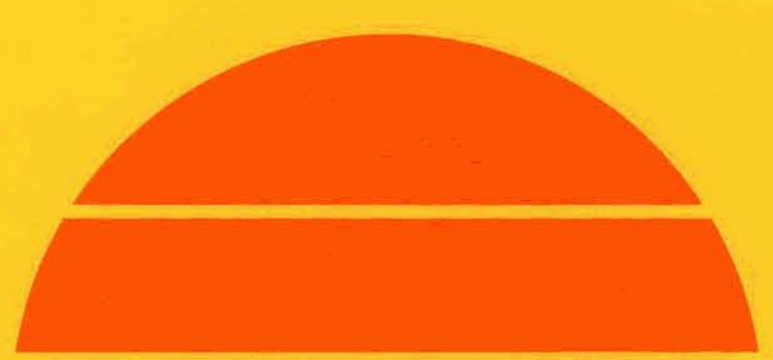

\section{U.S. Department of Energy}




\section{DISCLAIMER}

This report was prepared as an account of work sponsored by an agency of the United States Government. Neither the United States Government nor any agency Thereof, nor any of their employees, makes any warranty, express or implied, or assumes any legal liability or responsibility for the accuracy, completeness, or usefulness of any information, apparatus, product, or process disclosed, or represents that its use would not infringe privately owned rights. Reference herein to any specific commercial product, process, or service by trade name, trademark, manufacturer, or otherwise does not necessarily constitute or imply its endorsement, recommendation, or favoring by the United States Government or any agency thereof. The views and opinions of authors expressed herein do not necessarily state or reflect those of the United States Government or any agency thereof. 


\section{DISCLAIMER}

Portions of this document may be illegible in electronic image products. Images are produced from the best available original document. 


\section{NOTICE}

This report was prepared as an account of work sponsured by the United States Finvernment. Neither the United States nor the United States Department of Energy, nor any of their employees, nor any of their contractors, subcontractors, or their employees. makes any warranty, express or implied, or assumes any legal liability or responsibility for the accuracy, completeness or usefulness of any information, apparatus, product or process disclosed, or represents that its use would not infringe privately owned rights.

This report has been reproduced directly from the best available copy.

Available from the National Technical Information Service, U. S. Department of Commerce, Springfield, Virginia 22161.

Price: Paper Copy $\$ 4.00$

Microfiche $\$ 3.00$ 


\title{
SILICON HALIDE - ALKALI METAL \\ FLAMES AS A SOURCE OF SOLAR GRADE SILICON
}

\author{
SEVENTH QUARTERLY REPORT \\ D.B. OLSON AND R.K. GOULD
}

APRIL 1979

JPL Controct No. 954777

DRL- 4 ; DRD -QR

LSA Silicon Material Task

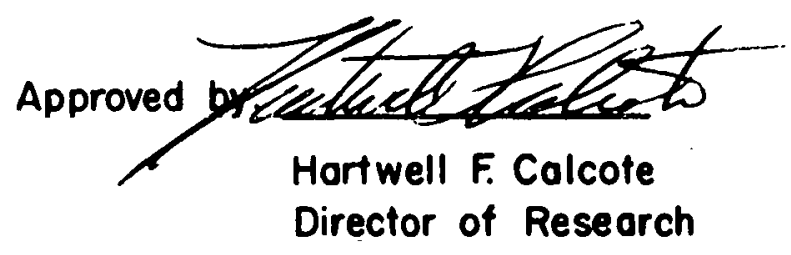

\section{Qherowem Research Laboratorles, Inc.}

\section{Princeton, New Jersey}




\section{FOREWORD AND ACKNOWLEDGMENTS}

This is the seventh quarterly progress report on a program which began 17 May 1977; it covers the period 1 January 1979 through 31 March 1979.

During this report period G. Rolland and L. Koenig made major contributions to the experimental effort on this program. 


\section{ABSTRACT}

This program is aimed at determining the feasibility of using high temperature reactions of alkali metals and silicon halides to produce low cost solar-grade silicon. Experiments are being performed to evaluate product separation and collection processes, measure heat release parameters for scaling purposes, and determine the effects of the reactants and/or products on materials of reactor construction. Prior work has demonstrated continuous separation of silicon from the byproduct alkali salt at a production rate of $0.5 \mathrm{~kg} \mathrm{~h}^{-1}$ in a graphite reactor using the reaction of $\mathrm{Na}$ with $\mathrm{SiCl}_{4}$. Silicon of similar purity is obtained from $\mathrm{Na}+\mathrm{SiF}_{4}$ flames although yields are lower and product separation and collection are less thermochemically favored.

During the current reporting period the results of heat release experiments have been used to design and construct a new type of thick-walled graphite reactor to produce larger quantities of silicon. A new reactor test facility has been constructed. Material compatibility tests have been performed for Na in contact with graphite and several coated graphites. All samples were rapidly degraded at $T=$ $1200 \mathrm{~K}$, while samples retained structural strength at $1700 \mathrm{~K}$. Pyrolytic graphite coatings cracked and separated from substrates in all cases. 


\section{TABLE OF CONTENTS}

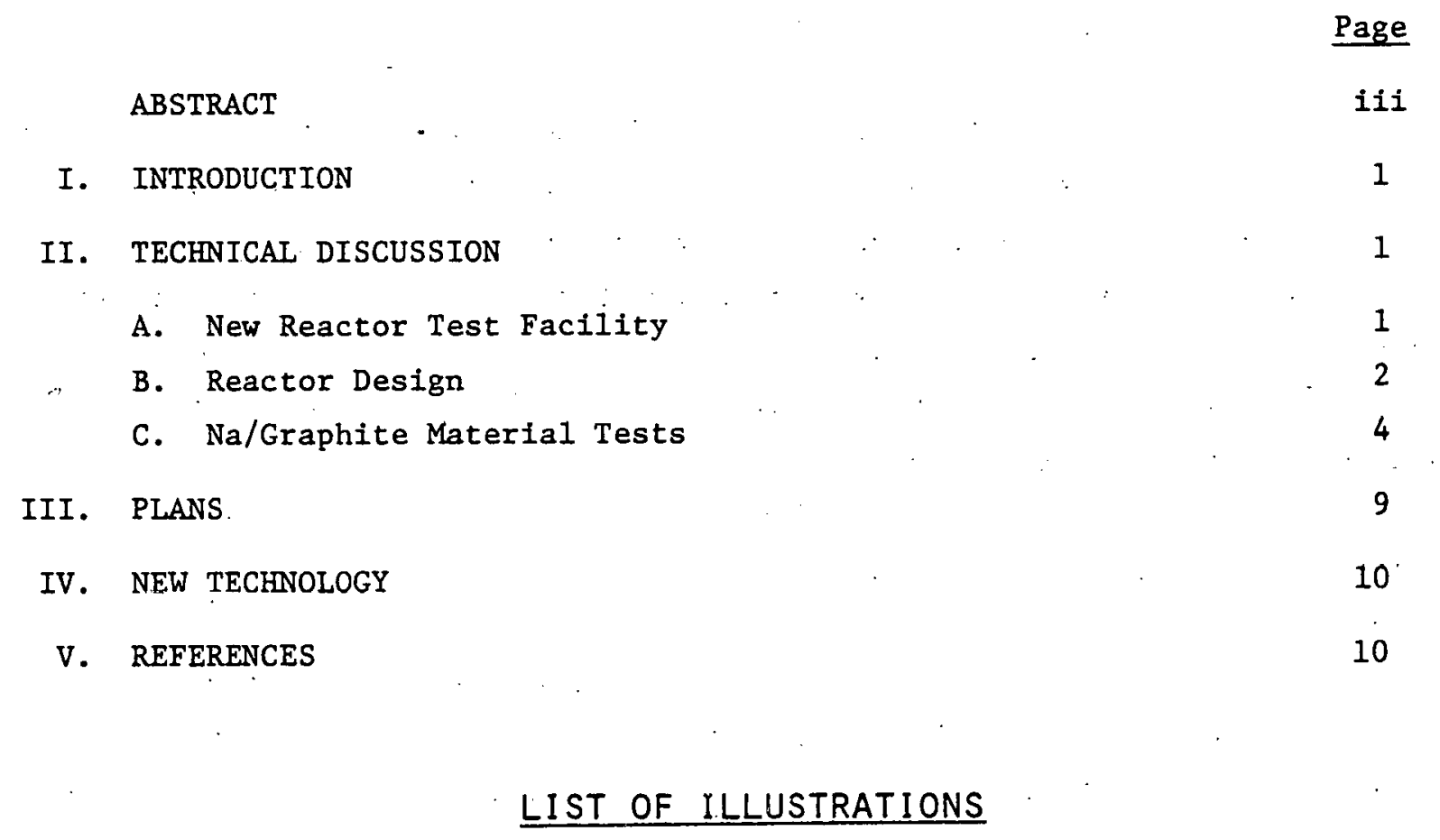

\section{$\underline{\text { Figure }}$}

1 THICK-WALLED GRAPHITE REACTOR

2 APPARATUS FOR Na/GRAPHITE TESTS AT $1150 \mathrm{~K}$

3 FLOW TUBE APPARATUS FOR Na/GRAPHITE TESTS AT $1200 \mathrm{~K}$ AND $1700 \mathrm{~K}$ 


\section{INTRODUCTION}

The object of this program is to determine the feasibility of using continuous high-temperature reactions of alkali metals and silicon halides to pro-. duce silicon in large quantities and of suitable purity for use in the production of photovoltaic solar cells. Reactions of gaseous $\mathrm{Na}$ or $\mathrm{K}$ with silicon halides (e.g., $\mathrm{SiCl}_{4}, \mathrm{SiHCl}_{3}$, or $\mathrm{SiF}_{4}$ ) are highly exothermic and luminescent, producing ${ }^{1}$ high adiabatic flame temperatures. Using reliable thermochemical data, equilibrium calculations ${ }^{2,9}$ show that silicon is the only condensed phase in the product stream; the alkali metal salt is in the vapor phase. This difference in physical state of desired and undesired products is a basis for separating the silicon from the byproduct salt. Therefore, one of the goals of this experimental program is to demonstrate the practicality of production/separation processes based on these conclusions and to obtain physical and chemical varlables useful for this and other high temperature silicon production processes. Additional studies are also being made of the compatibility of several graphite-based reactor materials with reactants and products of the process.

Prior work" showed that relatively pure silicon could be produced in low temperature reactors where the silicon and salt particles codeposited onto the walls. More recent experiments ${ }^{306}$ using a heated graphite reaction tube have demonstrated continuous high temperature separation of the silicon from the byproduct alkali metal salt. Reagent delivery systems have been built and operated at a production rate of $0.5 \mathrm{~kg} \mathrm{Si} \mathrm{h} \mathrm{h}^{-1}$. During this reporting period, we have completed the construction of (i) a new reactor facility, (il) a thick-walled graphite reactor of new design for larger silicon production, and (iii) a high temperature alumina flow. tube for Na/graphite compatibility tests. Results from these tests are discussed in Section. II of this report.

\section{TECHNICAL DISCUSSION}

\section{A. NEW. REACTOR TEST FACILITY}

The test station where the silicon production experiments are run has been extensively renovated. The reactor used up to now was constructed of $15 \mathrm{~cm}$ diam Pyrex process pipe. However, a larger volume chamber was needed, of all metal construction to eliminate safety problems when exterior wall heating occurs, and configured so that reactor tests can be conducted without completely disassembling 
and reconstructing the whole apparatus between successive runs. To meet these needs, a large $(65 \mathrm{~cm}$ diam, $80 \mathrm{~cm}$ high) stainless steel vacuum chamber with $2 \mathrm{~cm}$ thick aluminum end flanges has been purchased for the new experimental facility. All connections, vacuum, electrical, etc., are rigidly mounted on the fixed top flange. The water-cooled chamber can thus be quickly and easily lowered to gain access to the reactor. With this arrangement we expect to be able to test different reactor configurations, reactor construction materials, and operating modes with much shorter turn-around time than that required at present. The outer watercooled walls will provide surfaces for $\mathrm{NaCl}$ collection for the present time. This chamber and flanges have now been installed; the flanges have been bored to accept various fittings and feedthroughs and the construction is now complete. Vacuum leaks were eliminated after rewelding one of the commercially fabricated metal seams.

\section{B. REACTOR DESIGN}

Using the data obtained in our earlier heat release experiments, ${ }^{6}$ we conclude that the $\mathrm{Na} / \mathrm{SiCl}_{4}$ reaction goes rapidly to completion, and a smaller reactor volume is necessary than has been used in previous designs. A new reactor has been designed of smaller ( $8 \mathrm{~cm}$ diam, $16 \mathrm{~cm}$ long) reaction volume following these conclusions and is shown in Fig. 1.

Our aim is to collect high purity liquid silicon at the reactor outlet, with the $\mathrm{NaCl}$ (and, we hope, most other impurities) being collected on cooled surfaces far from the Si collector and thus show that product collection and separation is easily achieved in the absence of carrier gases such as $\mathrm{H}_{2}$ or $\mathrm{Ar}$. A major innovation in the new design concerns silicon particle separation from the $\operatorname{NaCl}(\mathrm{g})$. The exit from the reaction volume is configured as a small converging nozzle. In the initial tests the reactor will operate near 0.5 atm with the reactor walls near or above $1700 \mathrm{~K}$. The reaction products, $\operatorname{NaCl}(g)$ and $\operatorname{Si}(l)$, will leave the reactor through the nozzle, exhausting into a large volume held at a low ( $<10$ Torr) pressure. The jet from the reactor will impinge on a hot $(\approx 1700 \mathrm{~K}$ ) graphite crucible where the $\mathrm{Si}(l)$ droplets will be collected. The $\mathrm{NaC1}$ will condense on the cold walls of the vacuum chamber. Using the low pressure is not unreasonable for a process since essentially all of the reaction products are condensible. Hence, only a very small pumping capacity will be required to maintain a low pressure. The essential characteristics of this. silicon collection technique are that the $S i$ particles are given a large forward 


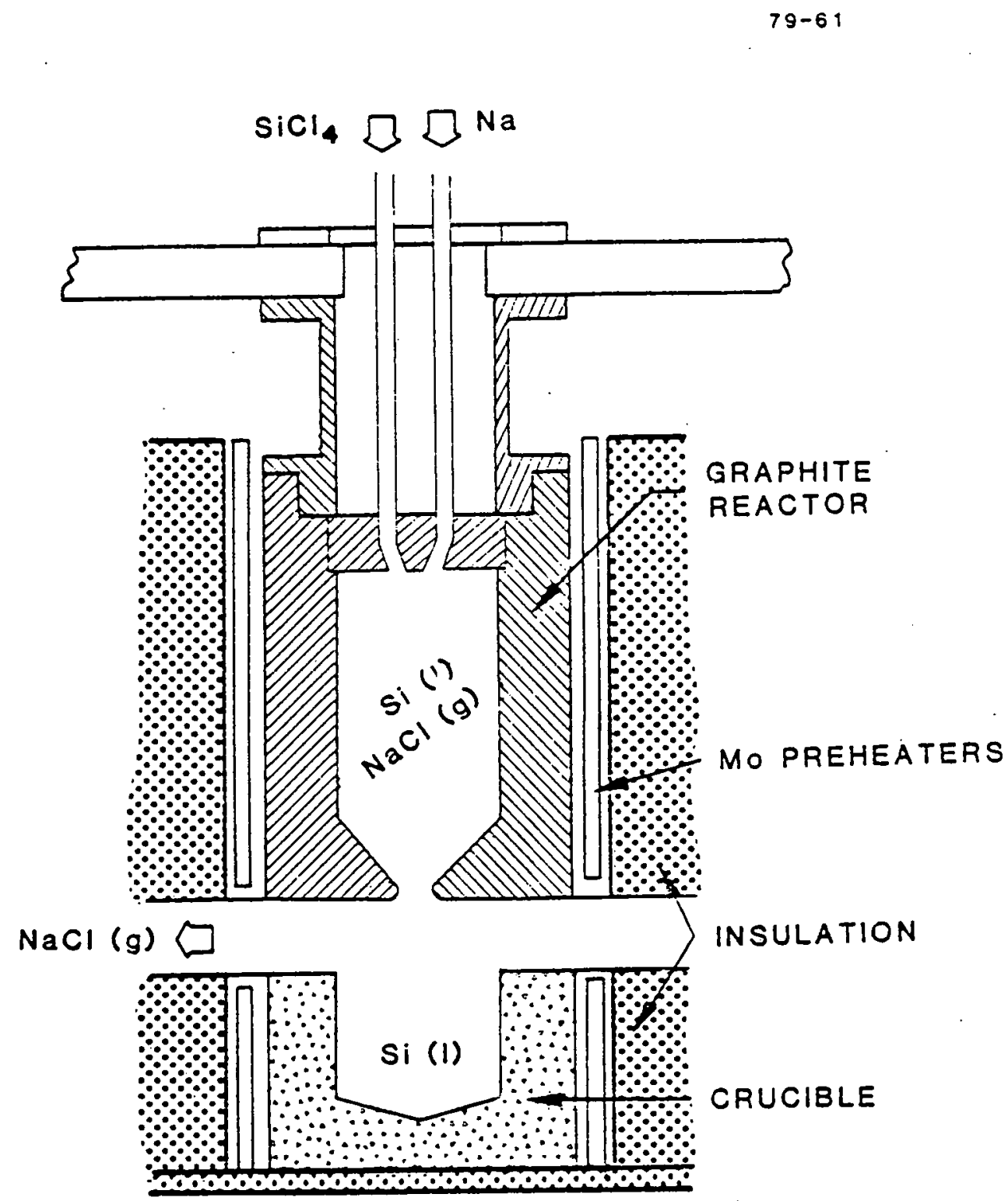

FIGURE 1 THICK-WALLED GRAPHITE REACTOR 
momentum in the nozzle, causing them to collect by impaction on the crucible. The lower pressure assists this process by increasing the stopping distance of the particles. Calculations indicate that even $0.01 \mu \mathrm{m}$ diam silicon droplets will penetrate $\approx 1$ into the shock layer above the Si liquid in the crucible. Impaction, diffusion. and thermophoretic collection will then remove many of even these very small droplets from the gas in this layer. Particles with $0.1 \mu \mathrm{m}$ diam will penetrate nearly $1 \mathrm{~cm}$ and will therefore impact the liquid surface. It will be of additional interest to test whether the thick graphite walls will withstand exposure to the reactants and products without structural damage.

\section{Na/GRAPHITE MATERIAL TESTS}

During this reporting period we have investigated the compatibility of several graphite materials with sodium. The results of these tests are of interest both to us in the design of our silicon production reactors and to those working on the Westinghouse ${ }^{7}$ arc-jet reactor.

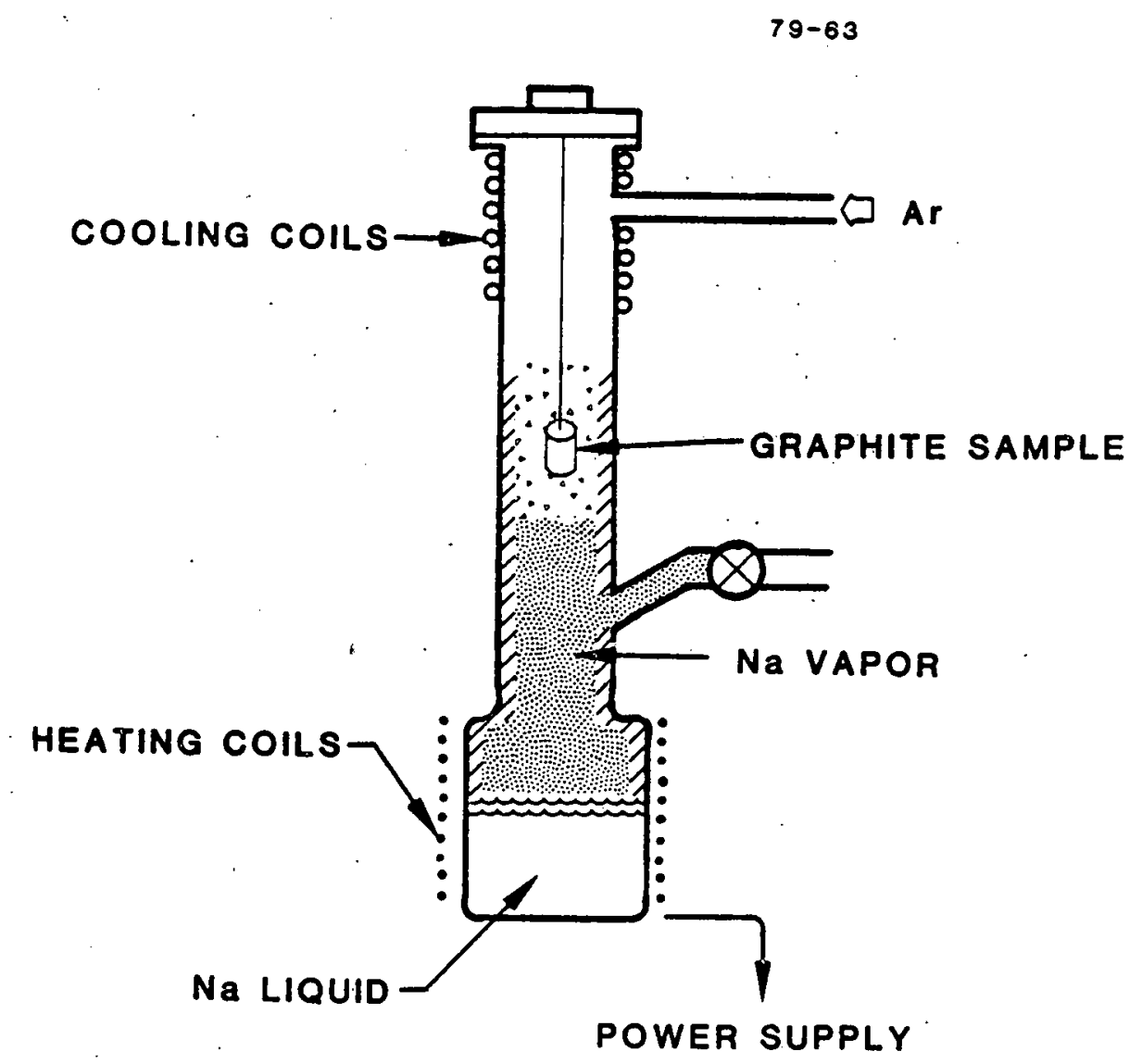

FIGURE 2 APPARATUS FOR Na/GRAPHITE TESTS AT $1150 \mathrm{~K}$ 
The first tests were performed as follows: Samples of graphite, nominally $3 \times 5 \mathrm{~cm}, 1-2 \mathrm{~cm}$ thick, were suspended by a wire in the sodium vapor generator ${ }^{2}$ at a level such that they would be immersed in the refluxing sodium vapor (see Fig. 2). The samples were exposed to refluxing sodlum at 0.5 atm and $1150 \mathrm{~K}$ for five minutes, cooled, and removed from the apparatus. Since these experiments were performed at the dew point of sodium, the samples were exposed to both liquid and vapor sodium. Table I lists the manufacturer, grade, and physical characteristics of the tested samples. According to the manufacturers' literature, these are high quality graphites. Alrco-Speer grade 580 is 1isted as "the densest and strongest extruded material commercially available." The Stackpole grade 2020 is a molded, high density material with small pore size. From Ultra Carbon we tested several coated graphites, including a pyrolytic graphite coated sample.

\section{TABLE I}

LIST OF MATERIALS TESTED IN CONTACT WITH SODIUM AT $1150 \mathrm{~K}$

Supplier/Grade

Alrco-Speer $/ 580$

A.D. Mackay/UF4S

Stackpole/2020

Ultra Carbon/PT-101

U1tra Carbon/PB-1300

UItra Carbon/PT-444

\section{Physical Characteristics}

Graphite, extruded; $1.76 \mathrm{~g} \mathrm{~cm}^{-3}$ density, $22 \%$ porosity, $0.020 \mathrm{~cm}$ maximum grain size.

Similar to Airco-Speer 580 grade but purified to $5 \mathrm{ppm}$ ash content.

Graphite; density $>1.77 \mathrm{~g} \mathrm{~cm}^{-3}$, $17 \%$ porosity, $0.004 \mathrm{~cm}$ maximum grain size, $1.5 \mu \mathrm{m}$ average pore size.

Pyrolytic graphite coated graphite; coating thickness estimated to be $\approx 0.005 \mathrm{~cm}$, substrate graphite grade unknown.

Silfcon carbide coated graphite; substrate graphite grade UT-22, $1.70 \mathrm{~g} \mathrm{~cm}^{-9}$ density, $21 \%$ porosity, $0.015 \mathrm{~cm}$ maximum grain size. Coating thickness unknown.

Silicon carbide coated graphite; manufacturer's code A-9648-6, substrate graphite properties unknown. 
The results of the tests were essentially the same for every sample. Both the coated and uncoated graphites emerged expanded, sustained multiple cracks, and, in some cases, were even broken. The silicon carbide coating could no longer be seen, while the pyrolytic graphite coating was cracked, broken, and peeling from its substrate. The samples were quenched in water to remove the sodium. After the initial reaction of sodium on the sample surface, evolution of bubbles was observed for hours, indicating that considerable sodium had permeated the samples.

We concluded from these simple tests that neither graphite, silicon carbide, or pyrolytic graphite coated graphlte is structurally stable in contact with sodium, at least near the sodium dew point.

In order to make further tests under more closely controlled conditions and at higher temperatures, a heated flow reactor was constructed. Although not expected to survive more than a few experiments, a $46 \mathrm{~cm}$ long, $5 \mathrm{~cm}$ diam alumina tube was used for the flow tube (see Fig. 3). The first $30 \mathrm{~cm}$ of the tube were wrapped with $0.127 \mathrm{~cm}$ (0.050 in.) diam Mo wire in three separate heater windings connected in parallel to an $\mathrm{AC}$ arc welder power supply capable of supplying about $250 \mathrm{~A}$. A dry run was performed with no reagents present in order to test this new flow tube design and also to check the functioning of the new reactor facility. The first test produced temperatures in excess of $2200 \mathrm{~K}$. Although the tube fractured at the end of the heated zone upon cooling, the failure was attributed only to our having heated the tube too rapidly and to too high a temperature. Consequently, another tube of similar design was constructed to replace it.

In order to perform tests directly applicable to the Westinghouse arc-jet reactor, ${ }^{7}$ we obtained from the same supplier samples of the specific grade of pyrolytic-coated graphite used in their design (Great Lakes Carbon Corp. grade HLM graphite coated with 0.013 to $0.025 \mathrm{~cm}(0.005$ to $0.010 \mathrm{in}$.) of pyrolytic graphite and supplied by Pfizer). These samples were approximately $2.5 \mathrm{~cm}$ long segments of $1.9 \mathrm{~cm}$ diam rod coated on all surfaces. Similarly coated samples of Stackpole grade 2020 graphite were also obtained from Pfizer. To test the compatibility of these samples with sodium vapor, one sample of each was suspended in a Mo wire basket at the mid-region of the heated flow tube (about 13 to $18 \mathrm{~cm}$ from the sodium inlet).

Conditions for these experiments were selected in cooperation with JPL Task I scientists ${ }^{\theta}$ to be an acceptable compromise between the exact Westinghouse 


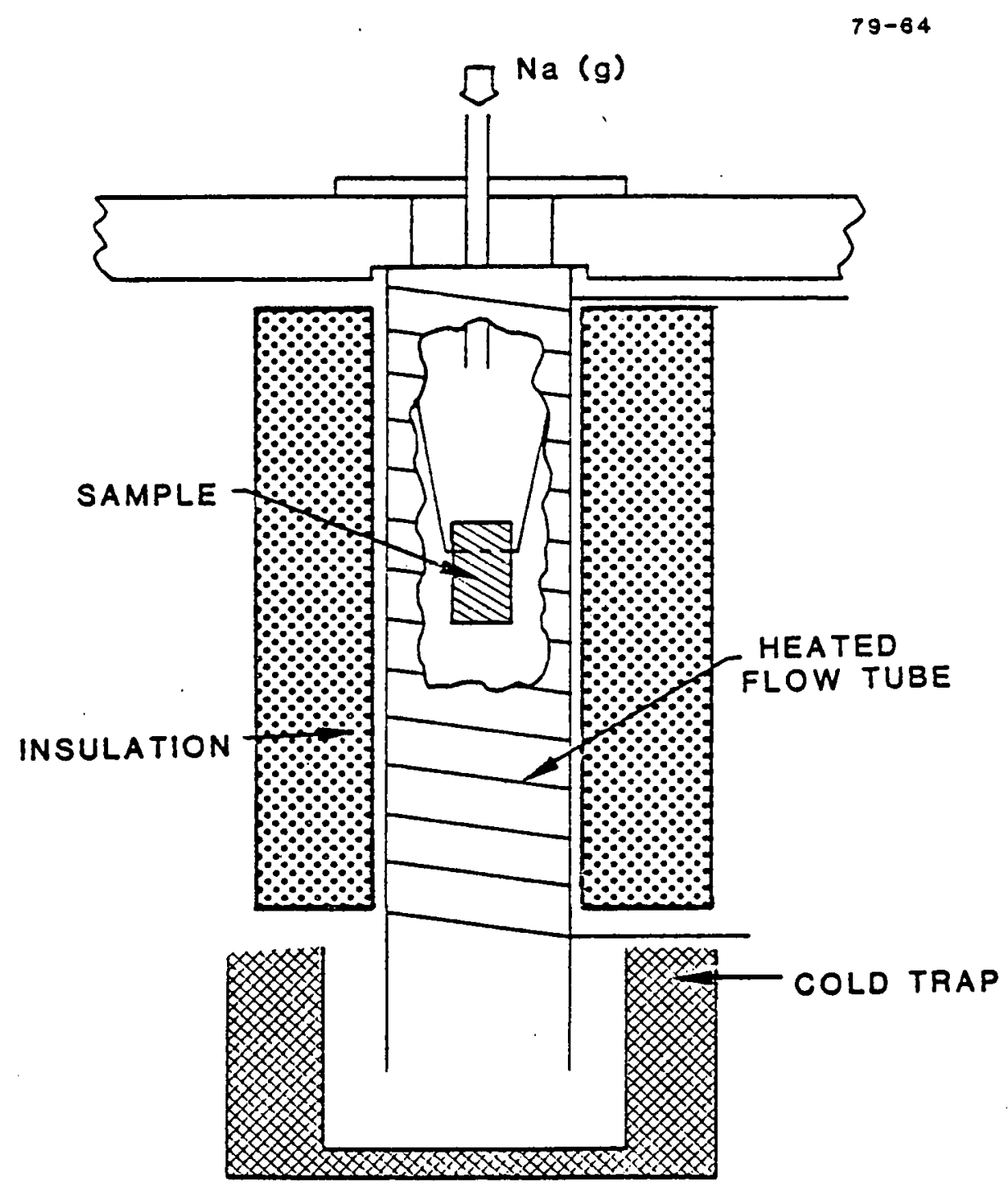

FIGURE 3 FLOW TUBE APPARATUS FOR Na/GRAPHITE TESTS

AT $1200 \mathrm{~K}$ AND $1700 \mathrm{~K}$ 
values and " se that could be achieved with existing apparatus here at Aerochem. Experiments were chosen to be performed at 1200 and $1700 \mathrm{~K}, 0.5 \mathrm{~atm}$ of undiluted sodium, a linear flow velocity of at least $2.5 \mathrm{~m} \mathrm{~s}^{-1}$, and an experiment duration of $0.5 \mathrm{~h}$ or longer. Table II gives the experimental conditions that were in fact achieved. Test 1 fell somewhat short of the goals in pressure and duration and Test 2 a bit short in duration. The resuits of Test 2 were, however, conclusive and Test 3 repeated the conditions of Test 1, so 1t is felt that sufficient data were taken for the desired purposes. The cold trap designed to capture and freeze

TABLE II

FLOW TUBE CONDITIONS FOR Na/GRAPHITE COMPATIBILITY TESTS

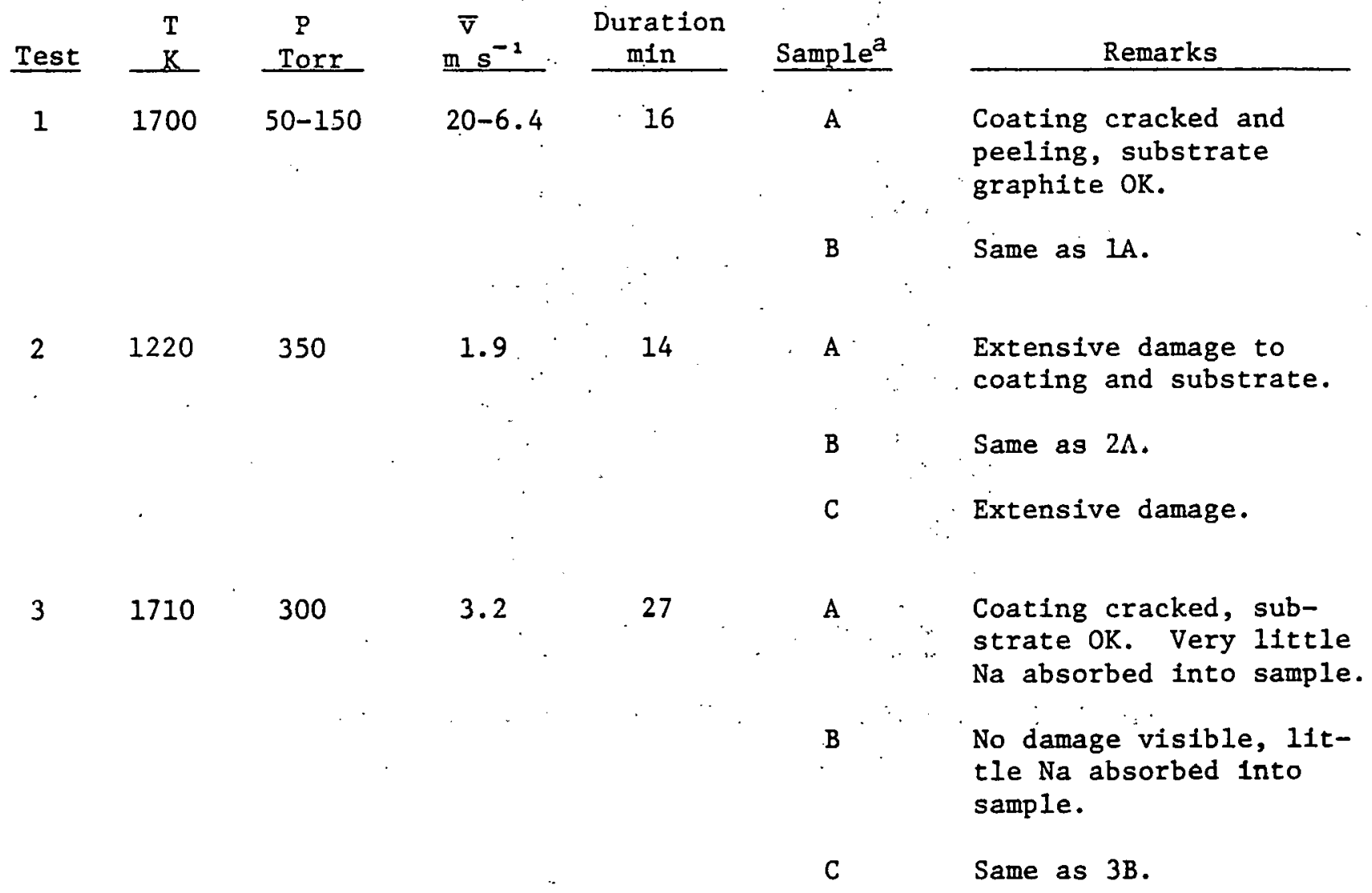

${ }_{A}$ = Pyrolytically coated graphite; Great Lakes Carbon Corp., HLM grade.

$B=$ Pyrolytically coated graphite; Stackpole, 2020 grade.

$C=$ Uncoated graphite; Airco-Speer, 580 grade. 
the Na vapor proved to be only partially effective and a cloud of small Na particles filled the reactor chamber. Test 1 was terminated at 16 min when the particle filter in the pumping line became clogged. The problem was most likely due to cooling the $\mathrm{Na}$ vapor too rapidly, and a higher temperature cold trap was used in the subsequent experiments. The $\mathrm{Na}$ dust in the chamber created somewhat of a cleanup hazard, requiring $\approx 24 \mathrm{~h}$ of surface passivation before the chamber could be opened to (moist) air.

Nonetheless, the experiments did provide good tests of the material in question. Two observations were immediately obvious. First, neither the pyrolytic coating nor any substrate graphite survived the test at 1150-1200 $\mathrm{K}$. A11 samples were cracked and expanded approximately 10 to $30 \%$. The results from the flow tube experiment at $1200 \mathrm{~K}$ correspond to those of the refluxing experiments performed in the Na vaporizer. The second observation was that the results are quite different at $1700 \mathrm{~K}$. A total of five samples were exposed to Na vapor at $1700 \mathrm{~K}$ and none sustained structural damage. The uncoated graphite sample showed no evidence of absorbed sodium. The pyrolytic graphite coating, however, was extensively cracked in three out of four samples. Probably if the Na gets under the coating at any imperfection it separates from the substrate and cracks. It is unlikely that any large-scale reactor could be made without some such imperfections.

The primary implication of this work with regard to the Westinghouse arcjet reactor is that the pyrolytically coated graphite reactor liner must be above $1200 \mathrm{~K}$ before exposure to the reagent flow.

\section{III, PLANS}

The new thick-walled graphite reactor, silicon collection crucible, and associated heaters, heat shields, thermocouples, etc. are about $3 / 4$ completed. During the next reporting perfod we plan to make this system operational and begin to make reactor and reaction studies; the former to determine the suitability of various reactor materials under a range of possible operating conditions, and the latter to determine the overall rates of chemical reactions and heat release. Product separation and collection efficiency will be measured as a function of pressure at the collector surface. 


\section{NEW TECHNOLOGY}

No reportable items of new technology have been identified.

\section{REFERENCES}

1. Miller, W.J., "Silicon Halide-Alkali Metal Flames as a Source of Solar Grade Silicon," First Quarterly Report, AeroChem TN-178, September 1977.

2. Miller, W.J., "Silicon Halide-Alkali Metal Flames as a Source of Solar Grade Silicon," Second Quarterly Report, AeroChem TN-182, December 1977.

3. Olson, D.B. and Miller, W.J., "Silicon Halide-Alkali Metal Flames as a Source of Solar Grade Silicon," Third Quarterly Report, AeroChem TN-187, ERDA/JPL 954777-78/3, March. 1978.

4. Olson, D.B. and Miller, W.J., "Silicon Halide-Alkali Metal Flames as a Source of Solar Grade Silicon," Fourth Quarterly Report, AeroChem TN-192, DOE/JPL 954777-78/4, June 1978.

5. Olson, D.B. and Miller, W.J., "Silicon Halide-Alkali Metal Flames as a Source of Solar Grade Silicon," Fifth Quarterly Report, AeroChem TN-199, DOE/JPL $954777-78 / 5$, October 19\%8.

6. Olson, D.B. and Miller, W.J., "Silicon Halide-Alkali Metal Flames as a Source of Solar Grade Silicon," Sixth Quarterly Report, AeroChem TN-201, DOE/JPL 954777-79/6, January 1979.

7. Fey, M.G., "Development of a Process for High Capacity Arc Heater Production of Silicon for Solar Arrays," Westinghouse Electric Corp., Quarterly Report, ERDA/JPL 954589-77/2, April-June 1977.

8. Private communication from R. Rhein and A. Briglio, January 1979. 